Canadian Journal of Higher Education

Revue canadienne d'enseignement supérieur

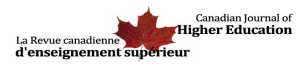

\title{
Beyond Face Value: A Policy Analysis of Employment Equity Programs and Reporting in Ontario Public Colleges
}

\section{Shani Kipang et Daniyal Zuberi}

Volume 48, numéro 2, 2018

URI : https://id.erudit.org/iderudit/1057109ar

DOI : https://doi.org/10.7202/1057109ar

Aller au sommaire du numéro

\section{Éditeur(s)}

Canadian Society for the Study of Higher Education

ISSN

2293-6602 (numérique)

Découvrir la revue

Citer cet article

Kipang, S. \& Zuberi, D. (2018). Beyond Face Value: A Policy Analysis of Employment Equity Programs and Reporting in Ontario Public Colleges. Canadian Journal of Higher Education / Revue canadienne d'enseignement supérieur, 48(2), 169-185. https://doi.org/10.7202/1057109ar
Résumé de l'article

Les collèges publiques au Canada jouent un rôle important en appuyant les étudiants qui font partie de groupes sous-représentés dans le systeme post-secondaire. Pourtant, au même temps qu'on voit une augmentation des inscriptions parmi ces groupes, cette diversité ne se reflète pas dans le corps enseignant des collèges publiques. La question de la diversité des professeurs a attiré plus drattention récemment dans les universités canadiennes, pourtant, ce n'est pas le cas dans les collèges. Cet article examine cette lacune en analysant les politiques de lıéquité en matière d`emploi dans les cinq plus grands collèges publics de l>Ontario (Ontario Colleges of Applied Arts and Technology, ou OCAATs). En examinant le recrutement des professeurs et la politique des ressources humaines-deux domaines qui sont sous-développés dans les collèges publiques au Canada — cet article présente des recommandations pour améliorer les politiques organisationnelles dans les collèges canadiens. 


\title{
Beyond Face Value:A Policy Analysis of Employment Equity Programs and Reporting in Ontario Public Colleges
}

\author{
Shani Kipang \& Daniyal Zuberi \\ University of Toronto
}

\begin{abstract}
Given their unique pedagogical mandate and structure, Canadian public colleges play a central role in serving groups traditionally under-represented in the post-secondary system. Yet as enrolment from these groups continues to rise, it is unclear to what extent the diversity of student bodies is reflected among faculty. In fact, while issues of faculty diversity and employment equity have gained increasing attention within Canadian universities, they have been largely overlooked within colleges. In an effort to address this gap, we have reviewed the employment equity related policies of Ontario's five largest publicly funded colleges (otherwise known as Ontario Colleges of Applied Arts and Technology, or OCAATs). With a focus on personnel data collection and recruitment-two policy areas we will argue are particularly underdeveloped in the sector-this paper provides recommendations for future research and priorities for organizational policy development.
\end{abstract}

\section{Résumé}

Les collèges publiques au Canada jouent un rôle important en appuyant les étudiants qui font partie de groupes sous-représentés dans le systeme postsecondaire. Pourtant, au même temps qu'on voit une augmentation des inscriptions parmi ces groupes, cette diversité ne se reflète pas dans le corps enseignant des collèges publiques. La question de la diversité des professeurs a attiré plus d>attention récemment dans les universités canadiennes, pourtant, ce n'est pas le cas dans les collèges. Cet article examine cette lacune en analysant 
les politiques del>équité en matière d`emploi dans les cinq plus grands collèges publics de l>Ontario (Ontario Colleges of Applied Arts and Technology, ou OCAATs). En examinant le recrutement des professeurs et la politique des ressources humaines-deux domaines qui sont sous-développés dans les collèges publiques au Canada-cet article présente des recommandations pour améliorer les politiques organisationnelles dans les collèges canadiens.

Given a changing economic climate and new workforce demands, public colleges in Canada play an increasingly important role in the country's post-secondary system. In addition to affordability, applied professional development, diversity, and flexibility, many colleges have joined universities in a mandate of research and innovation. Given this rapidly changing and unique positioning, the college sector also plays a central role in serving diverse and under-represented groups, particularly racialized, Indigenous, and newcomer students, and students with disabilities (Fujii, 2014; HRSDC, 2008; Tesa, 2013). Yet as enrolment from these groups continues to rise, it is unclear to what extent the diversity of these student bodies is reflected among the faculty of these institutions. In fact, while issues of faculty diversity and employment equity have been given increasing attention within Canadian post-secondary scholarship and in Canadian universities, there has been a lack of attention and research on this topic among public colleges.

The goal of this paper is to begin to address this gap and provide preliminary insights to ground future research. Using publicly available data, we present the findings of a review of the employment equity (EE) related policies of five Ontario colleges. With a focus on personnel data collection and recruitment-two policy areas that we argue are particularly underdeveloped in the sector-this paper provides recommendations for future research and priorities for organizational policy development.

\section{Background}

\section{Is Diversity More Than Employment Equity?}

Some studies on the experiences of marginalized and traditionally under-represented student populations have reported correlations between the degree of faculty representation-reflection of racial, cultural, gender, and other forms of student diversity-and increased markers of student success and satisfaction. For example, in conducting interviews with 155 female students in 30 science departments in the United States, Etzkowitz, Kemelgor, Neuschatz, Uzzi, and Alonzo (1994) found that reported experiences of isolation and exclusion among female students were noticeably diminished with modest increases in female faculty. While the authors offer the caution that this numerical achievement in itself did not resolve systemic issues of bias, discrimination, or practices supporting male hegemony, it can play a positive role in creating "alternative relational modes" for female students that can assist in their engagement and advancement (p. 54).

Similar findings have been reported in research on other student populations. In one survey investigating the experiences of 5,011 self-identified Latino students across nine schools in the Los Angeles Community College district, the researchers reported that the level of representation of Latino faculty on campus was found to have a "significant impact” on Latino student success (Hagedorn, Chi, Cepeda, \& Mclain, 2007, p. 89). Latino 
faculty were found to be role models for Latino students, and helped to foster a sense of belonging and social integration among them. Other researchers have suggested that representation of racialized and Indigenous faculty can additionally combat stereotypes about the educational aspirations of marginalized groups, and can help white students and faculty gain deeper understanding and appreciation for different cultures and perspectives (Linthicum, 1989; Opp \& Smith, 1994). Despite this, qualitative research with faculty of colour at U.S. community colleges reveals that they continue to face institutionally based systematic barriers that negatively impact their professional experience, selfimage, and performance (Levin, Jackson-Boothby, Haberier, \& Walker, 2015).

In Canada, lack of available data has made it more difficult to quantitatively assess direct implications of faculty diversity. However, the results of several related research projects suggest that this area warrants attention. One federal government study found that in comparison to self-identified Caucasian students, a lower proportion of both racialized and Indigenous college students indicated that they were "well integrated into college, both academically and socially" (HRSDC, 2008, p. 58). Similarly, a higher proportion reported "a weaker commitment to their program and institution" and felt "less likely to have a positive impression of the faculty" (HRSDC, 2008, p. 58).

The findings of the above study are not unique. In documenting the experiences of minority students in the Canadian $\mathrm{K}-12$ educational system, researchers have presented data suggesting systemic issues related to ethnocentric curriculum, marginalization, and stigmatization of racialized students (Dei, Mazzuca, McIsaac, \& Zine, 1997; Rummens \& Dei, 2010; James \& Taylor, 2008; Tilleczek \& Ferguson, 2013). For those students who continue into Canadian post-secondary education (PSE), there is significant scholarship to suggest that these concerns are equally relevant (Henry \& Tator, 1994; HernandezRamdwar, 2009; James, 2009; Marchak 1996; Ng, 1994). This argument is highlighted in Samuel and Burney's (2003) interviews with 22 second-generation South Asian students within a predominately white Ontario university. In this study, all 22 participants shared experiences of either isolation or marginalization: "I don't think I am a cultural fit in this university...faculty, peers and the culture around do not particularly accept me" (p. 101); perceived racism in both overt and covert forms: "These professors assume that you don't understand certain things that are explained in class and tend to explain more to you or speak slowly to you" (p. 95), or Eurocentricity in curriculum and teaching styles:

I think a Eurocentric bias exists at the level of what is considered good scholarly thought.... Therefore, work that deals with racism in texts is often devalued. I think this is especially hard for people of colour, because for me it's really hard for me to analyze a text or theory "objectively" when it reeks of racism. (p. 103)

While findings such as these highlight challenges within Canadian universities, additional research has focused specifically on the community college system. In one interview-based study, Peters (2004) investigates the experiences of 17 self-identified Black Ontarians who had "dropped out" of four different Toronto-area community colleges. Consistent with both the findings of the HRSDC (2008) and Samuel and Burney (2003), participants in this study similarly described a lack of connection with faculty, and sentiments that "teachers did not expect them to do well in school" and were perceived to behave paternalistically and condescendingly (Peters, 2004, p. 263). In addition, several 
participants commented on the lack of diversity among senior administrative and teaching staff, and expressed concerns that the lack of racial diversity impacts the "relevance of the learning experience and serves to exclude the Black experience" (p. 223). In addition to issues related to the curriculum, some participants expressed concerns regarding the lack of role models from their own community. In a sentiment echoing the findings of the study by Hagedorn et al. (2007), one participant described the lack of diversity in their college by stating that "such image[s] send strong message[s] to some students about their place in the society. Black people can be cleaning staff but not college president" (Peters, 2004, p. 224).

In summarizing how some of the participants felt that colleges were addressing these concerns, Peters (2004) reports:

Some participants suggested that Toronto colleges have done an excellent job of convincing Black students that race does not matter... [B]y ignoring race colleges could continue to ignore the needs of Black students. While Black students state that colleges may provide ethnic food outlets, they do not feel validated ideologically as Blacks because they feel that they are unable to talk honestly about their educational and personal development. Some participants suggest that they feel pressured to adopt a raceless or neutral cultural identity. (p. 266)

Canadian scholars working in this area have highlighted a wide range of necessary institutional changes. Among these, increasing diversity of faculty has been proposed not only as an issue of access and employment equity, but as an important step in reflecting the diverse demographics and meeting the needs of Canada's changing student bodies (Henry \& Tator, 1994; James, 2009; Peters, 2004; Samuel \& Burney, 2003). In fact, as a central conclusion to their study, Samuel and Burney (2003) argue that their findings reveal "an absolute necessity of filling in the gaps and inequities in academia, curriculum, and pedagogy by hiring more minority faculty who are representative of the demographic characteristics of Canadian society and in a manner consistent with Canadian Multiculturalism policy" (pp. 86-87).

\section{Strategies to Promote Faculty Diversity}

As many studies have shown, the task of promoting genuine equity and representation among PSE faculty is a multifaceted one. To be effective, it must be an ongoing and longterm process involving multiple levels of individual, institutional, and policy change. As it is beyond the scope of this paper to explore each of these layers, we focus on two areas of organizational policy that should be considered priorities for Ontario public colleges.

\section{Identifying Barriers through Monitoring and Evaluation}

In Canada, employment equity (EE) initiatives were spearheaded by the 1984 Royal Commission Report Equality in Employment. In this report the regular collection and monitoring of workforce demographic data was identified as a key component in creating and evaluating EE initiatives, and as a means of addressing barriers faced by specified "designated groups"-women, Aboriginal peoples, persons with disabilities, and members of visible minorities. According to its author, Chief Justice Rosalie Abella (1984): 
The success of an employment equity program is measured by results: expansion of the employment opportunities of qualified individuals in designated groups. Measurement of results requires data. The Commission recommends that employers be required to request and collect from their employees information on the participation in their workforces of women, native people...disabled persons, and specified ethnic and racial groups by occupational categories, and by salary range and quartile. An employee's self-identification of gender, race, ethnicity, or disability would be voluntary and confidential. (p. 6)

The collection of quantitative data as an equity and diversity strategy is not without its challenges-namely, the inherent risk of creating a workplace and policy culture in which over-emphasis on numerical goals can overshadow and/or undermine genuine structural change. Even with its limitations, however, there is significant evidence to suggest that this strategy plays a critical first step in identifying and addressing employment barriers (Jain \& Lawler, 2004; Nancarrow, 2002; Ng, Haq \& Tremblay, 2010).

The principal recommendations of the Abella report (1984) were enshrined into Canadian law in the form of the Employment Equity Act of 1986. Currently its sanctions, including those related to data collection-the collection of voluntary employee surveys self-identifying inclusion in the four designated groups-are mandated only for federally legislated sectors, those belonging to the Federal Contractors Program (FCP), Crown corporations, and other federal organizations with 100 employees or more, as well as portions of the federal public administration identified in Schedules I or IV and V of the Financial Administration Act. However, the recommendations of the Employment Equity Act are directed to all Canadian employers.

To date, there has been little effort within Canadian research to document the extent or manner in which employment equity data is collected or reported within post-secondary institutions. This is not surprising, given that the vast majority of Canadian public universities are members of the Federal Contractors Program, and thus mandated to collect and publicly report this data. In contrast, however, the vast majority of public colleges are not members of this federal program. In this case, conducting and publicly reporting personnel demographic data-as a means of identifying and addressing employment barriers-is voluntary and based on the schools' own interpretation of their employment equity mandate. As there has been no public or private research investigating this process, up to now we have little basis to assess the sector's compliance with this recommendation. Thus, in an era in which even private corporations now routinely collect and publicly report their personnel demographics as part of their public "diversity commitment," it is concerning how little we know about these policies in public colleges, a publicly funded educational sector.

\section{Recruitment}

Much of the literature on faculty diversity in PSE has traditionally focused on issues of recruitment and hiring. For some, the focus has been on long-term strategies addressing the arguable "pipeline problem"-the lack of interested and appropriately qualified candidates from under-represented communities (Roach, 2009; Shaw \& Stanton, 2012; Wallen, Rivera-Goba, Hastings, Peragallo, \& De Leon Siantz, 2005). Others, however, 
have questioned this approach as potentially diverting attention from other viable policy and practice alternatives. The case has been made for more attention to search committee composition and education, based on research that suggests both a lack of diverse representation and a lack of awareness among members of institutional employment equity mandates (American Federation of Teachers, 2010; de Los Santos, 1994; Fujii, 2014; Tesa, 2013). Additional research supports more targeted and coordinated recruitment campaigns, as researchers have argued that arbitrary recruitment and advertising practices may miss potential candidates from under-represented groups (Fujii, 2014; Opp \& Smith, 1994; Robertson \& Frier, 1994; Staples, 1984). Related to this are concerns about the continued existence in some institutions of informal hiring practices, referred to as "network-based hiring," which can perpetuate a workforce culture in which under-represented groups can be excluded from these informal networks, and an almost club-like environment that can result (Braddock \& McPartland, 1987; Fernandez \& Greenburg, 2013; Gemkow \& Neugart, 2011; Staples, 1984).

While these issues have received increasing attention in Canadian higher education research literature, these studies have focused almost entirely on universities. Yet one recent college-focused study on faculty hiring practices in five Ontario public colleges revealed a concerning finding. Based on interviews with 16 key informants ( 11 deans and five HR managers) involved in the creation of hiring and recruitment policies, Tesa (2013) found:

While HR managers were charged with the responsibility for ensuring compliance with Human Rights requirements throughout the selection process, there was no indication that selection committees sought candidates who would reflect the student diversity in their programs. Instead, their comments focused on their concerns over the lack of Canadian industry experience of the many candidates who had foreign PhD credentials. (p. 107)

These findings reinforce the need for additional research on the full-time recruitment policies and practices of Ontario colleges. Unfortunately, however, given current trends in post-secondary hiring, this may still miss an important point-that applying for fulltime faculty positions is no longer the initial point of entry for the vast majority of public college educators.

\section{Gaps in the Literature: Addressing New Realities in PSE}

In the context of what many are now calling a two-tiered (Oprean, 2012; Tesa, 2013) and even "caste-like" (Hodkinson, 2003, p. 4) system of post-secondary educators, studying issues of faculty representation has become even more complex. Like their counterparts in the United States and elsewhere, most Canadian colleges and universities are now increasingly characterized by a new neoliberal public management staffing structure. The use of contingent, non-tenured faculty has become significantly more prevalent. Similar to what is seen in the United States-where contingent instructors made up 76.4\% of higher-education faculty in 2011 (U.S. Department of Education, as cited in Curtis, 2014)-in Canadian provinces such as Ontario part-time instructors now make up over $67 \%$ of public college faculty, outnumbering full-time faculty at a ratio of over two to one (College Employer Council, as cited in Colleges Ontario, 2015). This has two impor- 
tant implications for diversity and equity. First, a growing body of research pointing to concerns of precariousness and compensation inequities in this structural arrangement (Hodkinson, 2003; Muzzin, 2003; Muzzin \& Limoges, 2008; Zabudsky, 2008) indicates significant social, political, and economic implications. In addition, there are concerns related directly to institutional excellence and student experience, including issues of student mentorship, program and curriculum development, and other non-teaching activities. Within the current system, faculty hired expressly for short-term teaching duties are not generally in a position to take on these additional roles. While the implications of this situation have been well documented (Bernhardt, 2009; Hodkinson, 2003; Zabudsky, 2008), there has been limited attention to the specific impact on students and faculty from marginalized communities.

While demographic research on contingent faculty in North America is limited, available data suggest that racialized minorities are more highly represented in this group as compared to the tenure-stream faculty. According to 2007 data from the U.S. Department of Education, of the $10.4 \%$ of faculty positions held by under-represented racial and ethnic groups, 7.6\% were contingent positions (as cited in American Federation of Teachers, 2010). Although comparable Canadian data are not available, researchers in this area suggest at least similar concerns (Muzzin, 2003; Spafford, Nygaard, Gregor, \& Boyd, 2006), indicating that general issues of faculty representation are only heightened by the ongoing entrenchment of the two-tiered system.

While numerical gains in diversity among contingent faculty is likely to assist in promoting the statistical appearance of a school's diversity mandate, it may accomplish little to address real structural gaps such as diverse perspectives in curriculum, program development, and mentorship opportunities for minority students. Hence, we argue that any relevant inquiry into employment equity policies must acknowledge discrepancies between faculty groups.

\section{Employment Equity Policies in Ontario Colleges}

In an effort to address the above gaps, we have conducted a policy review of Ontario's five largest publicly funded colleges (otherwise known as Ontario Colleges of Applied Arts and Technology or OCAATs). Based on 2012-2013 full-time student enrolment data (Colleges Ontario, 2015, the colleges included in this review are:

1. Humber Institute of Technology and Advanced Learning

2. Seneca College of Applied Arts and Technology

3. George Brown College of Applied Arts and Technology

4. Algonquin College of Applied Arts and Technology

5. Sheridan College Institute of Technology and Advanced Learning

The goal of this review is to assess the integration of employment equity mandates in the organizational policy areas of personnel data collection and recruitment. We rely on online data, publicly accessible policies, and publicly available information provided by the five human resources departments. Given the limited scope of this method, our goal is not to explore the applications or effectiveness of the schools' policies but simply to determine (1) whether the selected colleges have committed to an employment equity mandate, and (2) to what extent this mandate is addressed within data collection and recruitment policies. 


\section{Do Ontario Colleges Have an Equity Mandate?}

A review of the websites of five selected colleges found that all have committed to some form of diversity or equity mandate, although there appears to be variation in the extent to which these are identified as priorities in their overall administrative structure. As seen in Table 1, while George Brown and Humber colleges have created departments targeted directly to equity initiatives, the majority of the schools monitor their related policies through their offices of human resources. It should be noted that while Algonquin College does not have an equity department, it does have a position for a diversity and accessibility coordinator within its HR team. It is also interesting to note that the former Resolution, Equity, and Diversity centre of Seneca College has recently been merged with the Student Conduct Office.

While it is beyond the scope of this paper to analyze and compare the content of each of the policies presented in Table 1, there are several shared principles. These elements, while emphasized to varying degrees, are in line with the Ontario Colleges of Applied Arts and Technology 2014-2017 Collective Agreement. Excerpted from the agreement, they include a commitment to facilitate the following:

- The attainment of appropriate representation of targeted groups identified by the Province of Ontario;

- The implementation of practices and policies to enhance the hiring of, and transfer, promotion, training and developmental opportunities of, persons from designated groups; and

- Generating [and monitoring] data as to the current representation and distribution of the designated groups. (College Employer Council and Ontario Public Service Employees Union [CEC \& OPSEU], 2014, p. 92)

Table 1. Employment Equity and Diversity Related Policies in Ontario Colleges

\begin{tabular}{|c|c|c|}
\hline & Related policy & Department \\
\hline Seneca & Diversity Policy & $\begin{array}{l}\text { Student Conduct (formerly Resolu- } \\
\text { tion, Equity, and Diversity) }\end{array}$ \\
\hline George Brown & $\begin{array}{l}\text { Prevention of Discrimination and } \\
\text { Harassment Policy } \\
\text { AND } \\
\text { Race and Ethnic Relations Policy }\end{array}$ & $\begin{array}{l}\text { Diversity, Equity, and Human Rights } \\
\text { Services }\end{array}$ \\
\hline Algonquin & Diversity and Equity Policy & $\begin{array}{l}\text { Human Resources (under Diversity } \\
\text { and Accessibility Coordinator) }\end{array}$ \\
\hline Sheridan & $\begin{array}{l}\text { Harassment and Discrimination } \\
\text { policy }\end{array}$ & Human Resources \\
\hline Humber & $\begin{array}{l}\text { Employment Equity policy } \\
\text { AND } \\
\text { Diversity policy }\end{array}$ & $\begin{array}{l}\text { Centre for Human Rights, Equity, } \\
\text { and Diversity }\end{array}$ \\
\hline
\end{tabular}


As each of the selected colleges is a signatory to the OCAAT Collective Agreement, they can each be considered to have a documented EE mandate. Further, given the specific obligations of this commitment outlined above, personnel data collection and recruitment practices must be considered central to this mandate.

\section{Data Collection and Self-Identification Surveys}

In the spirit of the Employment Equity Act and the Abella report (1984), collecting and reporting EE data is not simply a case of reporting overall statistics, such as the percentage of designated groups in the overall workforce or among faculty as a whole. Rather, as specifically outlined in the OCAAT agreement, the distribution of designated groups is also of key significance. In other words, given concerns that racialized and other designated groups may be overrepresented among contingent faculty, these distinctions are of particular importance.

In Table 2, we have outlined central policies of personnel data collection in the five colleges. As a point of comparison, we have outlined policies in Ontario's five largest universities. While it must be noted that these two sectors are by no means matched in funding sources or institutional size, they could be argued to be analogous enough in mandate and scope of service to warrant comparison of policies on representation and diversity of faculty.

Existence of EE data. As presented in Table 2, of the five colleges surveyed, four currently conduct Employment Equity Self-identification (EESI) surveys. Humber-which is the only member of the Federal Contractors Program-is mandated to collect these surveys. The other three colleges do so voluntarily.

Public reporting. Of the five colleges, only Humber makes the results of its EESI surveys available in a public annual report. George Brown released the data upon request, but at the time of this review did not have any report available on its website. Algonquin and Seneca use the data only for internal purposes.

Distinction between faculty groups. At George Brown, EE data is collected from full-time faculty annually, and separately from contingent faculty every five to seven years. At Humber, data are collected from both full-time and contingent staff annually. In their public reporting of this data, however, there is no distinction between faculty groups, with all percentages reported under the general "faculty" categorization (Humber College, 2015).

Data collection-recommendations. It is promising that most of the schools have acknowledged the need to collect workforce data and complete analyses as a means of identifying employment barriers. There are two important gaps, however, in this process. First, in the interest of transparency, it would be helpful for all schools to publicly disclose this information as a sign of accountability to students, staff, and the community. This could also address student concerns, such as those described by Peters (2004), that Canadian public colleges are "ignoring race" and thus by extension ignoring the needs of racialized students (p. 266). In sharing with their communities their real challenges and efforts towards equity and diversification among the faculty, colleges can demonstrate a genuine commitment to creating equitable and representative staff bodies. 
Table 2. Employment Equity Data-collection in Ontario Colleges and Universities

\begin{tabular}{lccc}
\hline & $\begin{array}{c}\text { Employment equity } \\
\text { data collected }\end{array}$ & $\begin{array}{c}\text { Publicly accessible } \\
\text { data }\end{array}$ & $\begin{array}{c}\text { Reports distinguish } \\
\text { faculty tiers }\end{array}$ \\
\hline $\begin{array}{l}\text { Public colleges } \\
\text { Humber }\end{array}$ & $\mathrm{X}$ & $\mathrm{X}$ & - \\
George Brown & $\mathrm{X}$ & $\mathrm{X}$ & $\mathrm{X}$ \\
Seneca & $\mathrm{X}$ & - & $\mathrm{n} / \mathrm{a}$ \\
Algonquin & $\mathrm{X}$ & - & $\mathrm{n} / \mathrm{a}$ \\
Sheridan & - & $\mathrm{n} / \mathrm{a}$ & $\mathrm{n} / \mathrm{a}$ \\
Public universities & & & \\
University of Toronto & $\mathrm{X}$ & $\mathrm{X}$ & $\mathrm{X}$ \\
York University & $\mathrm{X}$ & $\mathrm{X}$ & $\mathrm{X}$ \\
University of Ottawa & $\mathrm{X}$ & $\mathrm{X}$ & $\mathrm{X}$ \\
Ryerson University & $\mathrm{X}$ & $\mathrm{X}$ & $\mathrm{X}$ \\
University of Western & $\mathrm{X}$ & $\mathrm{X}$ & $\mathrm{X}$ \\
Ontario & & & \\
\hline
\end{tabular}

A second concern is the lack of distinction in data reporting among faculty groups. While Humber is leading the way in publicly reporting its EE data (as required by the FCP mandate), the current format of the equity data publication is problematically only at the aggregate level. In failing to distinguish between faculty tiers, or at least distinguishing between full-time and contingent faculty, it provides only limited assessment of key dimensions of progress in this area. Given concerns regarding the role of contingent faculty (i.e., precariousness, lack of involvement in program and curriculum development, etc.), the research on the importance of faculty diversity for student outcomes suggests that the data be used in such a way to also identify potential barriers between faculty tiers. As this distinction is a matter of transparency and should require few extra resources, it is recommended that each of the institutions consider this a priority in their data collection and reporting policy.

\section{Recruitment Policies}

Transparency. As seen in Table 3, of the five colleges surveyed, only Algonquin and Seneca follow a publicly accessible hiring policy. In the case of Seneca, this policy is more of a policy statement or philosophy, outlining a general set of guiding principles and a commitment to develop procedures which "eliminate, redress and prevent disadvantages in employment for under-represented groups and establish a workforce that is representative of the College's diverse community" (Seneca College, 2015, p. 1). In this case, the procedures themselves are not disclosed.

The Algonquin hiring policy is a detailed 31-step procedure to be used as a guide for all full-time hires. It includes steps in the advertisement, recruitment, and interviewing stages. With the exception of a recommendation that all hiring committees include "as much as possible, representatives from both genders" (Algonquin College, 2015), the policy does not refer to employment equity, diversity, or representation. 
Policies governing part-time hiring. Within the current OCAAT Collective Agreement, limited provisions are included for posting and recruiting full-time faculty positions. Among these, for example, it is stipulated that all full-time bargaining unit positions must be posted "for at least five working days" (CEC \& OPSEU, p. 68). Notably, these provisions do not apply to part-time faculty (those who, according to the collective agreement, teach seven hours or less in a semester), as these faculty are not currently unionized. While this distinction does not prevent colleges from creating individualized hiring policies for part-time staff, in each of the schools surveyed, procedures for parttime hiring do not fall under the scope of HR policies, and are thus frequently left to the discretion of individual departments. ${ }^{1}$ While most colleges do generally advertise parttime vacancies, practices such as informal recruitment of part-time staff or recruitment based on recommendation are not currently prohibited in any of the five schools, and appear to be common in practice.

Table 3. Recruitment Policies in Ontario Colleges and Universities

\begin{tabular}{lccc}
\hline & $\begin{array}{c}\text { Step-by-step } \\
\text { procedures available } \\
\text { to public }\end{array}$ & $\begin{array}{c}\text { Policies govern } \\
\text { full-time recruitment } \\
\text { process }\end{array}$ & $\begin{array}{c}\text { Policies govern } \\
\text { part-time recruitment } \\
\text { process }\end{array}$ \\
\hline $\begin{array}{l}\text { Public college recruitment policies } \\
\text { Humber }\end{array}$ & - & $\mathrm{X}$ & - \\
George Brown & - & $\mathrm{X}$ & - \\
Seneca & - & $\mathrm{X}$ & - \\
Algonquin & $\mathrm{X}$ & $\mathrm{X}$ & - \\
Sheridan & & $\mathrm{X}$ & - \\
Public university recruitment policies & & \\
York & $\mathrm{X}$ & $\mathrm{X}$ & $\mathrm{X}$ \\
Toronto & $\mathrm{X}$ & $\mathrm{X}$ & $\mathrm{X}$ \\
Ryerson & $\mathrm{X}$ & $\mathrm{X}$ & $\mathrm{X}$ \\
McMaster & $\mathrm{X}$ & $\mathrm{X}$ & $\mathrm{X}$ \\
Western Ontario & $\mathrm{X}$ & $\mathrm{X}$ & $\mathrm{X}$ \\
Guelph & $\mathrm{X}$ & $\mathrm{X}$ & $\mathrm{X}$ \\
\hline
\end{tabular}

Recruitment-implications and recommendations. The findings of this review suggest a significant gap in this area of college human resources policy. First, as a matter of transparency and accountability, it is concerning that only one of the colleges surveyed has a publicly accessible hiring procedure. It is perhaps even more concerning that this procedure, like those reportedly followed by the other colleges, applies only to full-time hiring. Given that contingent faculty are given formal priority in the hiring process over external candidates (CEC \& OPSEU, 2014, p. 68), it is troubling that more attention is 
not paid to the process by which prospective employees make it through this initial door. As discussed, this form of informal, network-based hiring process can result in significant concerns around equity, access, and subtle forms of discrimination. While the existence of policies alone cannot feasibly eliminate these types of practices, it is at the very least a first step in transforming institutional culture.

While many of these practices persist due to their perceived convenience and practicality, their continued use in this sector contributes to problems in representation and perhaps quality. Hence we recommend that Ontario colleges follow the lead of most other publicly funded sectors, including the university sector, in developing detailed, publicly accessible recruitment policies to apply to all staff and faculty.

\section{Areas for Future Research}

The goal of this paper was to provide very preliminary insights into the integration of employment equity mandates in Canadian public college policies. We have focused on a case study of five public colleges in Ontario. Given the findings, it appears clear that substantial research is needed, especially in other Canadian provinces and in a comparative perspective to other countries. The public college sector remains understudied in the Canadian employment equity literature, and further research could contribute significantly to our understanding of the current system and its challenges.

In the meantime, colleges in Canada should follow through on their expressed equity commitments and adopt policy reforms to improve representation, especially of disadvantaged and under-represented groups among their tenure-stream faculty. Perhaps most important will be the connection from policy to practice. As we know from other sectors, the development of policies alone is unlikely to result in sustainable organizational change. Thus, effective reform requires ongoing data collection, evaluation, and followup research to improve practical implementation of equity policies as they are developed and improved. The reflexive process of reform and implementation will help not only to identify and address gaps and challenges but also to assist in a collaborative learning process in which schools can benefit from the experiences of others.

While employment equity policies play an important role in creating more diverse faculties and programs, it is also important that the focus not be limited to this domain alone. For example, one area that is particularly worth exploring is strategies for the integration of contingent faculty. Given concerns of overrepresentation of racialized and other minority faculty in this group, we suggest that college administrators work on both long-term solutions such as identifying barriers to minority recruitment, retention, and advancement, as well as more immediate reforms in the direction of more inclusive and equitable internal structures. For example, data suggest that contingent college faculty are often denied opportunities-or, more commonly, (equitable) compensation-for work such as curriculum development, committee involvement, or participation in program planning and advisory meetings (Bernhardt, 2009). This is a concern for equity but also pedagogical quality. Without taking advantage of the unique resources, knowledge base, and experience offered by contingent faculty (presumably, based on the data, considerably more diverse than that of full-time faculty alone), colleges are depriving students of important learning and professional development opportunities. However, such a shift will in most cases require a significant revisiting of budget priorities and compensation structures. 
To address barriers to policy reform and implementation, the collection and publication of relevant data in this area-for example, mapping the macro-level demographics of Canadian college faculties or documenting the current and potential roles and impacts of contingent faculty from designated groups-will also help address an important gap in the current policy discourse and knowledge base of this sector.

\section{Conclusion}

In a global economy, where hands-on skills and training are increasingly the key to securing rewarding employment, the Canadian public college system is rapidly expanding its significance in the PSE landscape. As such, it is no longer acceptable that it be held to a lower standard of equity, accountability, or transparency in faculty representation. In fact, given what public colleges have demonstrated in resourcefulness, innovation, and responsiveness to the needs of diverse populations, they should be considered uniquely positioned to lead in this area of policy development and practice. Colleges that accept this role and demonstrate a genuine investment in structural change will only strengthen their relevance and reputation as leading-edge educational institutions. More importantly, in creating the building blocks for pedagogical frameworks rooted in diversity, equity, and anti-racism, they will be better equipped to address the needs and realities of all students, and particularly those from groups who remain under-represented and underserved by Canadian post-secondary systems.

\section{Acknowledgements}

The authors would like to thank research assistant Kelsey Block for editorial assistance and the Social Sciences and Humanities Research Council of Canada (SSHRC) and Ontario Graduate Fellowship program for funding support.

\section{References}

Abella, R. (1984). Equality in employment: A Royal Commission report. Ottawa, ON: Minister of Supply and Services.

Algonquin College (2015) Algonquin College Full Time Hiring Process. Retrieved from Algonquin College website: http://www.algonquincollege.com/policies/policy/fulltime-hiring-process/

American Federation of Teachers. (2010). Promoting racial and ethnic diversity in the faculty: What higher education unions can do. Retrieved from https://www.aft.org/ sites/default/files/facultydiversityo310.pdf

Bernhardt, R. G. (2009). The potential for engaging part-time faculty in community colleges in additional roles: Perceptions and attitudes of part-time faculty and administrators (Doctoral dissertation). Retrieved from ProQuest Dissertations \& Theses Global. (Order No. NR52613)

Braddock, J. H., \& McPartland, J. M. (1987). How minorities continue to be excluded from equal employment opportunities: Research on labor market and institutional barriers. Journal of Social Issues, 43(1), 5-39. 
Calliste, A. (2000). Anti-racist organizing and resistance in academia. In A. M. Calliste \& G. J. S. Dei (Eds.), Power, knowledge and anti-racism education: A critical reader (pp. 141-161). Halifax, NS: Fernwood Publishing.

Canadian Association of University Teachers. (2004). Closing the equity gap: A portrait of Canada's university teachers, 1996-2001. CAUT Education Review, 6(2), 1-5.

Canadian Council on Learning. (2006). Report on learning in Canada 2006: Canadian postsecondary education: A positive record: An uncertain future. Retrieved from www. ccl_cca/CCL/Reports/PostSecondaryEducation/Archives2006/index.html

College Employer Council and Ontario Public Service Employees Union (CEC \& OPSEU). (2014). Collective Agreement between College Employer Council for the Colleges of Applied Arts and Technology and Ontario Public Service Employees Union, September 1, 2014-August 31, 2018. Retrieved from https://opseu.org/sites/default/ files/final_2014-2018_supp_staff_ca_final_eng_for_web.pdf

Colleges Ontario. (2015). Environmental scan: College resources. Retrieved from http://www.collegesontario.org/research/2015_environmental_scan.html\#

Curtis, J.W. (2014). The employment status of instructional staff members in higher education, Fall 2011. Washington, DC: American Association of University Professors. Retrieved from https://www.aaup.org/sites/default/files/files/AAUP-InstrStaff2011April2014.pdf

Dei, G. J. S., \& James, I. M. (2002). Beyond the rhetoric: Moving from exclusion, reaching for inclusion in Canadian schools. Alberta Journal of Educational Research, 48(1), 61-87.

Dei, G. J. S., \& Karumanchery, L. L. (1999). School reforms in Ontario: The marketization of education and the resulting silence on equity. Alberta Journal of Educational Research, 45(2), 111-131.

Dei, G. J. S., Mazzuca, J., McIsaac, E., \& Zine, J. (1997). Reconstructing “drop-out": A critical ethnography of the dynamics of Black students' disengagement from school. Toronto, ON: University of Toronto Press.

de Los Santos, A. G. (1994). Minority faculty recruitment and retention strategies: The Maricopa experience. New directions for community colleges, 1994(87), 73-80.

Etzkowitz, H., Kemelgor, C., Neuschatz, M., Uzzi, B., \& Alonzo, J. (1994). The paradox of critical mass for women in science. Science New Series, 266(5182), 51-54.

Fernandez, R. M., \& Greenberg, J. (2013). Race, network hiring, and statistical discrimination. Research in the Sociology of Work, 24, 81-102. doi:http://dx.doi. org/10.1108/So277-2833(2013)0000024007

Fujii, S. J. (2010). Observations, values, and beliefs about ethnic/racial diversity by members of community college faculty search committees (Doctoral dissertation). Retrieved from ProQuest Dissertations \& Theses Global. (Order No. 3432292)

Fujii, S. J. (2014). Diversity, communication, and leadership in the community college faculty search process. Community College Journal of Research and Practice, 38(10), 903-916. 
Gemkow, S., \& Neugart, M. (2011). Referral hiring, endogenous social networks, and inequality: An agent-based analysis. Journal of Evolutionary Economics, 21(4), 703-719. doi:http://dx.doi.org/10.1007/s00191-011-0219-3

Hagedorn, L. S., Chi, W., Cepeda, R. M., \& Mclain, M. (2007). An investigation of critical mass: The role of Latino representation in the success of urban community college students. Research in Higher Education, 48(1), 73-91. doi:http://dx.doi.org/10.1007/ s11162-006-9024-5

Henry, F., \& Tator, C. (1994). Racism and the university. Canadian Ethnic Studies, 26(3), 74-90.

Hernandez-Ramdwar, C. (2009). Caribbean students in the Canadian academy: We've come a long way? In F. Henry \& C. Tator (Eds.), Racism in the Canadian university (pp. 106-127). Toronto, ON: University of Toronto Press.

Hodkinson, D. S. (2003). Faculty in higher education: Adjunct realities within a dual system (Doctoral dissertation). Retrieved from ProQuest Dissertations \& Theses Global. (Order No. 3094053)

Humber College (2015) Employment Equity Statistic at Humber. Retrieved from Humber College website: https://humanresources.humber.ca/assets/files/human rights/Employment_Equity_Statistics_at_Humber_2013.pdf

Human Resources and Skills Development Canada (HRSDC). (2008). Pan-Canadian study of first year college students: Report 2: The characteristics and experience of Aboriginal, disabled, immigrant and visible minority students. Retrieved from http:// publications.gc.ca/site/eng/343901/publication.html

Jain, H. C., \& Lawler, J. J. (2004). Visible minorities under the Canadian Employment Equity Act, 1987-1999. Industrial Relations/Relations Industrielles, 59(3), 585-609.

James, C. (2009). "It will happen without putting in place special measures": Racially diversifying universities. In F. Hentry \& C. Tator (Eds.), Racism in the Canadian university (pp. 137-159). Toronto, ON: University of Toronto Press.

James, C. E., \& Taylor, L. (2008). "Education will get you to the station":

Marginalized students' experiences and perceptions of merit in accessing university. Canadian Journal of Education, 31(3), 567-590.

Linthicum, D. S. (1989). The dry pipeline: Increasing the flow of minority faculty. Paper presented at the League for Innovation in the Community College Conference Leadership 2000, San Francisco, CA.

Levin, J. S., Jackson-Boothby, A., Haberier, Z., \& Walker L. (2015). "Dangerous work": Improving conditions for faculty of color in the community college. Community College Journal of Research and Practice, 39(9), 852-864. doi:http://dx.doi.org/10.1080/1066 8926.2014.917596

Marchak, M. P (1997). Racism, sexism \& the university: The political science affair at the University of British Columbia. Montreal, QC: McGill-Queens University Press.

Mooney, C. J. (1989). Affirmative-action goals, coupled with tiny number of minority Ph.D.'s, set off faculty recruiting frenzy. The Chronicle of Higher Education, 35(47), A10-A11. 
Muzzin, L. (2003). How fares equity in an era of academic capitalism? The role of contingent faculty. Paper presented at the Canadian Federation of the Humanities and Social Sciences International Colloquium on Transformation of Academic Culture: Capital Accumulation and International Competitiveness, Halifax, NS.

Muzzin, L., \& Limoges, J. (2008). “A pretty incredible structural injustice”: Contingent faculty in Canadian university nursing. In A. Wagner, S. Acker, \& K. Mayuzumi (Eds.), Whose university is it anyway? Power and privilege on gendered terrain (pp. 157-172). Toronto, ON: Sumach Press.

Nancarrow, L. (2002). The impact of workgroup diversity on organizationaloutcomes (Doctoral dissertation). Retrieved from ProQuest Dissertations \& Theses Global. (Order No. MQ68319)

Ng, E., Haq, R., \& Tremblay, D. G. (2010). A review of two decades of employment equity in Canada: Progress and propositions. In Klarsfeld, A., (Ed.), International handbook on diversity management at work: Country perspectives on diversity and equal treatment (pp. 46-67). Cheltenham, England: Edward Elgar Publishing.

$\mathrm{Ng}$, R. (1994). Sexism and racism in the university: Analyzing a personal experience. Canadian Woman Studies, 14(2), 41-46.

Opp, R. D., \& Smith, A. B. (1994). Effective strategies for enhancing minority faculty recruitment and retention. New Directions for Community Colleges, 23(87), 43-55. doi:http://doi.org/10.1002/cc.36819948707

Oprean, C. P. (2012). Hiring, orientation, professional development, and evaluation: The administrative support of adjunct faculty (Doctoral dissertation). Retrieved from ProQuest LLC. (Order No. 3545376)

Peters, K. M. (2004). Blackstudents and highereducation: Dropping out of community college (Doctoral dissertation). Retrieved from ProQuest Dissertations \& Theses Global. (Order No. NQ91850)

Roach, R. (2009). A pipeline to the tenure track. Diverse: Issues in Higher Education, 26(4), 9-12.

Robertson, P. F., \& Frier, T. (1994). Recruitment and retention of minority faculty. New Directions for Community Colleges, 1994(87), 65-71.

Rummens, J. A., \& Dei, G. J. S. (2010). Including the excluded: De-marginalizing immigrant/refugee and racialized students. Education Canada, 5o(5), 48-53.

Rummens, J. A., \& Dei, G. J. S. (2013). Marginalization inside education: Racialized, immigrant, and Aboriginal youth. In K. Tilleczek \& H. B. Ferguson (Eds.), Youth, education, and marginality: Local and global expressions (pp. 115-134). Waterloo, ON: Wilfrid Laurier University Press.

Samuel, E., \& Burney, S. (2003). Racism, eh? Interactions of South Asian students with mainstream faculty in a predominantly white Canadian university. The Canadian Journal of Higher Education, 33(2), 81-114.

Seneca College (2015) Seneca College Recruitment and Selection. Retrieved from Seneca College website: http://www.senecacollege.ca/policies/recruitment.html 
Shaw, A. K., \& Stanton, D. E. (2012). Leaks in the pipeline: Separating demographic inertia from ongoing gender differences in academia. Proceedings: Biological Sciences, 279(1743), 3736-3741. doi:http://dx.doi.org/10.1098/rspb.2012.0822

Smith, D. G., Turner, C. S., Osei-Kofi, N., \& Richards, S. (2004). Interrupting the usual: Successful strategies for hiring diverse faculty. The Journal of Higher Education, 75(2), 133-160.

Spafford, M. M., Nygaard, V. L., Gregor, F., \& Boyd, M. A. (2006). "Navigating the different spaces": Experiences of inclusion and isolation among racially minoritized faculty in Canada. The Canadian Journal of Higher Education, 36(1), 1-27.

Staples, R. (1984). Racial ideology and intellectual racism: Blacks in academia. The Black Scholar, 15(2), 2-17.

Tesa, A. L. (2013). The impact of degree-granting requirements on faculty hiring policies and practices: A case study of Ontario's institutes of technology and applied learning (ITALs) (Doctoral dissertation). Retrieved from ProQuest Dissertations \& Theses Global. (Order No. 3667313)

Tilleczek, K., \& Ferguson, H. B. (Eds.). (2013). Youth, education, and marginality: Local and global expressions. Waterloo, ON: Wilfrid Laurier University Press.

Wallen, G. R., Rivera-Goba, M., Hastings, C., Peragallo, N., \& De Leon Siantz, M. L. (2005). Developing the research pipeline: Increasing minority nursing research opportunities. Nursing Education Perspectives, 26(1), 29-33.

Zabudsky, J. D. (2008). Life, learning and work patterns of contingent community college faculty in the face of neoliberalism (Doctoral dissertation). Retrieved from ProQuest Dissertations \& Theses Global. (Order No. 687857857)

\section{Contact Information}

Daniyal Zuberi

Factor-Inwentash Faculty of Social Work and

Munk School of Global Affairs and Public Policy

University of Toronto

daniyal.zuberi@utoronto.ca

Shani Kipang is a PhD student at the Factor-Inwentash Faculty of Social Work at the University of Toronto.

Daniyal Zuberi is RBC Chair and Professor of Social Policy at the Factor-Inwentash Faculty of Social Work and Munk School of Global Affairs and Public Policy at the University of Toronto. 